\title{
Sleep-disordered breathing and hormones
}

\author{
T. Saaresranta*,\#, O. Polo*,\#
}

Sleep-disordered breathing and hormones. T. Saaresranta, O. Polo. C) ERS Journals Ltd 2003.

ABSTRACT: Sleep-disordered breathing (SDB) is not only a problem of the upper airway but is a systemic condition with endocrine and metabolic interactions. The accumulating body of evidence shows that SDB induces changes in the serum levels or secretory patterns of several hormones. Conversely, various endocrine disorders and hormone therapies may induce, exacerbate or alleviate SDB.

Much of the understanding of the interactions between hormones and sleepdisordered breathing derive from intervention studies with nasal continuous positive airway pressure therapy. Better understanding of hormones and breathing may open new perspectives in developing strategies to prevent, alleviate or cure sleep-disordered breathing and its systemic consequences.

Eur Respir J 2003; 22: 161-172.
*Dept of Pulmonary Diseases, Turku University Central Hospital and "Sleep Research Unit, Dept of Physiology, University of Turku, Turku, Finland.

Correspondence: T. Saaresranta, University of Turku, Sleep Research Unit, Lemminkäisenkatu 2, 20520 Turku, Finland.

Fax: 35823337520

E-mail: tarja.saaresranta@tyks.fi

Keywords: Cardiovascular diseases, continuous positive airway pressure, hormones, sleep apnoea, treatment

Received: July 102002

Accepted after revision: February 252003

This study was supported by the Finnish AntiTuberculosis Association Foundation, Emil Aaltonen Foundation and Paulo Foundation.
Sleep-disordered breathing (SDB) is an extremely common condition that compromises the vital functions of respiration and circulation. There is a myriad of adaptive physiological responses that are activated when cellular gas exchange and acid-base balance are endangered. Therefore, SDB has widespread systemic effects, which are, unfortunately, rarely considered by medical professionals other than those specialised in diagnosing and treating this disorder. The many adaptive endocrine alterations associated with SDB are an example of how a seemingly local upper airway dysfunction induces systemic consequences, affecting every cell of the organism. Conversely, manifestation of sleep apnoea is critically linked with control of breathing. All endocrine changes that increase the tendency for periodic breathing will also increase the episodes of sleep apnoea. The present review focuses on SDB secondary to various abnormal endocrine states and on the physiological endocrinological responses to primary SDB. The specific aspects of treatment of SDB in endocrine disorders are also discussed and some treatment strategies, based on the literature, are suggested.

The concept of SDB has markedly evolved during the past decade. The episodes of sleep apnoea and hypopnoea result from periodic total or partial closure of the upper airway. These episodes are often accompanied by hypoxaemia and terminated with cortical electroencephalogram arousals. The severity of SDB is commonly expressed as the apnoea/hypopnoea index (AHI), which indicates the frequency of the apnoea/ hypopnoea episodes per hour of sleep. Some authors also include the respiratory effort-related arousals and express the severity of SDB as the respiratory disturbance index (RDI). Most studies referred to in the present review define SDB in terms of AHI or RDI. Prolonged episodes of obstructive hypoventilation (upper airway flow limitation, partial obstruction) are acknowledged, but commonly not entered into the severity indices.

Sleep apnoea seems like an epidemic, which spreads rapidly with obesity, another major health problem in Western societies. In the USA, $24 \%$ of male and $9 \%$ of female government workers present with episodes of sleep apnoea or hypopnoea of five or more per hour [1]. Daytime symptoms of sleep apnoea appear in $4 \%$ of males and $2 \%$ of females [1]. Similar prevalence rates of symptomatic sleep apnoea in adults aged 20-100 yrs are reported in a community-based study: $3.9 \%$ in males and $1.2 \%$ in females [2].

A number of hormones interact with sleep [3] and breathing [4]. SDB affects hormones via a number of mechanisms. Conversely, hormones and endocrine states induce, aggravate or alleviate SDB. Finally, nasal continuous positive airway pressure (CPAP) therapy influences hormone secretion.

SDB and sleep disturbances may interact with hormones in several ways. Episodes of apnoea or hypopnoea cause sleep fragmentation and disturb sleep cycles and stages. Arousals may induce stress response resulting in increased levels of stress hormones [5]. Hypoxia may also have direct effects on central neurotransmitters [6], which result in alterations in the hypothalamo-pituitary axis and in secretion of the peripheral endocrine glands [7]. Hypercapnia alone or combined with hypoxia may increase levels of renin, adrenocorticotrophic hormone, corticosteroids, aldosterone and vasopressin [8, 9]. Finally, disorganisation of sleep, sleep loss and naps disturb sleep-controlled endocrine rhythms resulting in endocrine and metabolic abnormalities.

The direct and indirect effects of hormones and endocrine disorders on sleep and breathing are mediated via several pathways. Male sex and postmenopausal state, as risk factors $[10,11]$, link sex hormones to the pathophysiology of SDB. 
Table 1.-Prevalence of sleep-disordered breathing in some endocrine disorders and states

\begin{tabular}{|c|c|c|c|}
\hline Endocrine disorder & Prevalence of sleep apnoea $\%$ & Reference & Sample size \\
\hline \multirow[t]{2}{*}{ Diabetes type 1} & 31 & [24] & 16 \\
\hline & 42 & [25] & 12 \\
\hline \multirow[t]{2}{*}{ Diabetes type 2} & 1.9 (versus 0.3 in nondiabetics) & [26] & 579 \\
\hline & 36 (versus 14.5 in nondiabetics) & [27] & 25 \\
\hline \multirow{3}{*}{$\begin{array}{l}\text { Diabetes with autonomic } \\
\text { neuropathy }\end{array}$} & 37 (versus 0 in those without $\mathrm{AN}$ ) & [24] & 8 (and 8 without $\mathrm{AN}$ ) \\
\hline & 0 (versus 6 in those without $\mathrm{AN}$ ) & [28] & 8 (and 8 without $\mathrm{AN}$ ) \\
\hline & 26 (versus 0 in those without $\mathrm{AN}$ ) & [29] & 23 (and 25 without $\mathrm{AN}$ ) \\
\hline \multirow[t]{4}{*}{ Hypothyroidism } & 82 & [18] & 11102026 \\
\hline & 100 & [19] & \\
\hline & 25 & [20] & \\
\hline & 7.7 (versus 1.9 in controls) & {$[21]$} & \\
\hline \multirow[t]{6}{*}{ Acromegaly } & 40 with active, $0 \%$ with inactive disease & {$[12]$} & 10 with active, 11 with inactive disease \\
\hline & 45 & [13] & 11 \\
\hline & 81 & {$[14]$} & 53 \\
\hline & 91 & {$[15]$} & 11 \\
\hline & 39 & [16] & 54 \\
\hline & 75 & [17] & 55 \\
\hline Cushing disease/syndrome & 45 & {$[22,23]$} & 22 \\
\hline \multirow[t]{2}{*}{ Polycystic ovary syndrome } & 17 & {$[30]$} & 53 \\
\hline & 44 & [31] & 18 \\
\hline Postmenopause & $2.7^{\#}$ (versus 0.6 in premenopausal females) & {$[2]$} & 314 \\
\hline
\end{tabular}

$\mathrm{AN}$ : autonomic neuropathy. ${ }^{\#}$ : the prevalence in females is without hormone replacement therapy.

Sleep apnoea is common in acromegaly [12-17], hypothyroidism [18-21] or Cushing's syndrome [22, 23] (table 1). The most recent studies suggest that SDB may not only complete the clinical picture but play a central role in the pathophysiology of obesity [32], leptin resistance [33-35] or the metabolic syndrome $[32,36,37]$. The prevalence estimates of sleep apnoea among various endocrine states and disorders are shown in table 1 .

Unfortunately, there is a lack of well-documented epidemiological studies and thus most prevalence estimations are based on small study populations. Prevalence estimates are also limited because of different definitions of SDB. Many studies investigating the effects of SDB or nasal CPAP therapy on hormone levels have only assessed single morning levels of hormones, and therefore the effects on the 24-h secretory profile are poorly known.

\section{Metabolic syndrome and diabetes}

Sleep fragmentation resulting in sleep deprivation is likely to have an impact on hormones that regulate glucose tolerance. Partial sleep restriction (4-h sleep $\cdot$ night $^{-1}$ for 6 days) resulted in increased cortisol levels and impaired glucose tolerance even in healthy nonobese young males [38]. These metabolic and endocrine alterations were recuperated during recovery sleep. There is an accumulating body of evidence that SDB is linked with insulin resistance and metabolic syndrome independently of body mass index (BMI) and other known risk factors [32, 36, 37] (fig. 1). Oxygen desaturation index (drops of oxygen saturation of $\geqslant 4 \% \cdot \mathrm{h}^{-1}$ ) is a better predictor of insulin resistance than BMI [39]. In females with polycystic ovary syndrome, insulin resistance is a stronger risk factor for sleep apnoea than BMI or serum testosterone levels [30].

The prevalence of SDB in type-1 diabetes remains to be confirmed. Some authors have reported a prevalence rate of sleep apnoea as high as $42 \%$ [25], whereas others have not observed a difference from the general population [28]. Small sample sizes and different diagnostic criteria for sleep apnoea may explain some of the discrepancy. Diabetic children $(n=25)$

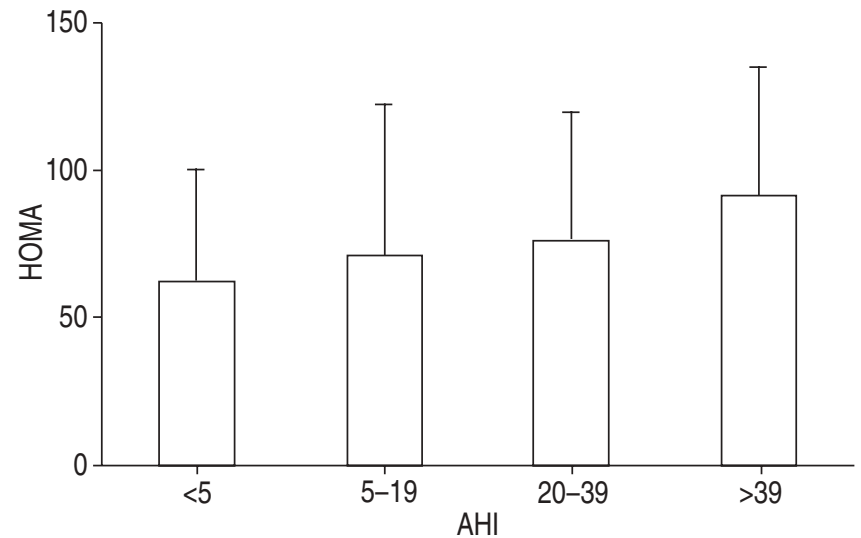

Fig. 1.- Index of insulin sensitivity calculated with a homeostasis model assessment $\left(\mathrm{HOMA}=\mathrm{G}_{0} \times \mathrm{I}_{0} / 22.5\right.$, where $\mathrm{G}_{0}$ and $\mathrm{I}_{0}$ represent fasting serum glucose and insulin, respectively) in different apnoea/ hypopnoea index (AHI) categories ( $n=150$ males). Subjects with increasing AHI are increasingly resistant to insulin. p-Value is significant for trend across AHI categories $(\mathrm{p}<0.05)$. Based on data from [37].

have more episodes of apnoea during sleep and the duration of apnoeic events is longer than in healthy controls [40]. Further, the degree of severity of sleep apnoea correlates with the glucose control and the duration of diabetes.

Among 13,000 Japanese hospital inpatients, the prevalence of sleep apnoea was $0.3 \%$ [26]. In a subgroup of $\sim 600$ male type- 2 diabetics, the prevalence of sleep apnoea was higher than in nondiabetics (1.9 versus $0.3 \%$, respectively). In a Swedish 10-yr follow-up study, snoring was a risk factor for diabetes, independent of other risk factors [41]. Among hypertensive diabetics, the prevalence of sleep apnoea, defined as AHI $\geqslant 20$, was $36 \%$ compared with $14.5 \%$ in nondiabetics [27]. Autonomic diabetic neuropathy may be associated with sleep apnoea. Among 23 diabetics with autonomic neuropathy (one had type-1 diabetes), six had sleep apnoea, whereas none of the diabetics without autonomic neuropathy were affected [29]. 


\section{Leptin}

Besides its best known function as a satiety hormone, leptin is also a powerful respiratory stimulant [42]. Plasma leptin levels are higher in sleep apnoeics than in controls matched for BMI [43]. Furthermore, hypercapnic patients with obstructive sleep apnoea syndrome (OSAS) have higher leptin levels than eucapnic BMI-matched controls with sleep apnoea [44]. Leptin secretion could provide an adaptive mechanism to enhance ventilation in patients with severe respiratory impairment. Conversely, high circulating leptin levels suggest leptin resistance at the level of the central nervous system. Elevated leptin levels are likely to contribute to comorbidity of OSAS because high leptin levels are associated with coronary heart disease [45], insulin resistance [46], impaired fibrinolysis [47], development of obesity [48], or type-2 diabetes [49], which are all highly prevalent in patients with OSAS.

\section{Catecholamines}

In blood and urine, high levels of catecholamines and their metabolites reflect increased sympathetic activity. Muscle sympathetic nerve activity is greater in obese than in normal-weight subjects [50], and greater in sleep apnoeics than in age- and BMI-matched controls [51, 52]. Hypoxia and hypercapnia induce sympathetic nervous system overactivity [53]. The sympathetic responses to hypoxia and hypercapnia are further potentiated during apnoea, when the inhibitory influence of the thoracic afferent nerves is eliminated [50, 52]. Nocturnal noradrenaline levels correlate with OSAS severity and oxygen saturation $[54,55]$. Also sleep fragmentation leading to chronic partial sleep loss is likely to contribute to the increased sympathoadrenal activity and increased circulating catecholamine levels encountered in OSAS. This assumption is supported by observations in healthy male volunteers [56]. One night of partial sleep deprivation resulted in increases in circulating noradrenaline and adrenaline levels [56]. Most studies report a positive relationship between episodes of obstructive apnoea and noradrenaline levels, whereas a minority of studies have found a relationship between adrenaline and episodes of obstructive apnoea [57, 58].

\section{Hypothyroidism}

A link between SDB and hypothyroidism is suggested by the high prevalence of sleep apnoea among hypothyroid patients, particularly in rare myxoedematous patients (7.7$100 \%$ ) [18-21] (table 1). Therefore, symptoms of SDB should be routinely asked in all hypothyroid patients and sleep studies should be considered when symptoms present.

The increased prevalence of SDB appears to be related to obesity and male sex rather than hypothyroidism per se [21]. However, decreased ventilatory responses [59], extravasation of albumin and mucopolysaccharides in the tissues of the upper airway [60, 61] and hypothyroid myopathy [19] have been suggested as possible contributing factors for SDB in hypothyroidism.

The decreased ventilatory responses increase with thyroxin replacement [59, 62], and episodes of apnoea may disappear [18-20, 63]. After initiation of thyroxin replacement therapy, patients may snore more [20], suffer from nocturnal chest pain and ventricular arrhythmia [19]. A temporary worsening of SDB after onset of thyroxin therapy could be due to an increase in basal metabolic rate, increased oxygen consumption and increased respiratory drive, which could promote periodic breathing and upper airway instability. Prolonged episodes of apnoea and lower oxyhaemoglobin saturation could be risky in patients with pre-existing coronary heart disease. To avoid the possible complications, hypothyroid patients with SDB should be, at least, initially treated with nasal CPAP. When the steady state has been achieved and the patient no longer has symptoms of hypothyroidism, the need for nasal CPAP therapy has to be re-evaluated.

In patients with OSAS, the prevalence of hypothyroidism is $1-3 \%[20,64,65]$, which does not essentially differ from that in the general population. Screening for hypothyroidism in patients with sleep apnoea does not seem necessary unless the patient is symptomatic or belongs to a risk group (i.e. females aged $\geqslant 60$ yrs) [65].

\section{Acromegaly}

The association of snoring and daytime sleepiness and acromegaly was first reported more than a century ago [66]. Macroglossia and pharyngeal swelling are the most probable reasons for the high incidence of SDB in acromegaly [67-70] (table 1). Accordingly, sleep apnoea alleviates when tissue hypertrophy decreases with somatostatin analogue treatment [71-73]. Growth hormone and insulin-like growth factor (IGF)-I may also have a direct role in the pathogenesis of sleep apnoea but the observations are controversial [12-14, $16,74]$. Some investigators report an association between the presence of sleep apnoea and high growth hormone and IGF-I levels [12, 16, 74], whereas the others fail to show any association between obstructive sleep apnoea and biochemical activity of acromegaly $[13,14]$. One study found an association between the biochemical activity of acromegaly and central sleep apnoea [14]. The high IGF-I levels in acromegaly may drive breathing and result in increased hypercapnic ventilatory response measured during wakefulness [71], and increased frequency of central apnoea [71] or periodic breathing with symmetric waxing and waning respiratory efforts [15] during sleep.

Treatment of acromegaly with adenomectomy [16] or octreotide [71] may cure acromegaly related OSAS. The operative team should be aware of the risks of performing the transsphenoidal adenoma resection in acromegalic patients with sleep apnoea in whom upper airway oedema could potentially further aggravate gas exchange postoperatively [67]. Octreotide treatment may promptly alleviate OSAS, and thus its preoperative administration is recommended [72, 75-77]. Preoperative nasal CPAP therapy could also reduce the perioperative risks [77]. Sedatives have to be avoided and monitoring of breathing should be extended beyond the immediate postoperative period. Perioperative tracheostomy is the safest and sometimes the only alternation to secure breathing after surgery.

After adenomectomy, sleep apnoea persists in every fifth patient, in particular, in those whose growth hormone levels remain high [16]. In addition to endocrine factors, the high prevalence of residual SDB after adenomectomy could be related to soft tissue hypertrophy, which remains unaltered. However, uvulopalatopharyngoplasty is not feasible in the treatment of acromegaly related OSAS [78]. Nasal CPAP with new pressure titration is often needed after surgery [77].

\section{Growth hormone deficiency}

Not only excessive growth hormone production, but also growth hormone deficiency could link with sleep apnoea. 
Syndromes with hereditary growth hormone deficiency are often associated with obesity, craniofacial and pharyngeal abnormalities predisposing to SDB. However, in lack of comprehensive studies only anecdotal case reports about Laron dwarfism [79] and Turner syndrome [80] would support this. In Prader-Willi syndrome, severe growth hormone deficiency occurs in $38 \%$ of adults [81]. The pathological somnolence in Prader-Willi patients could be due to nonapnoeic breathing abnormalities rather than episodes of sleep apnoea [82].

Sleep apnoea patients have low growth hormone levels without any specific causes of growth hormone deficiency [83]. Growth hormone secretion occurs mostly during sleep, and $70 \%$ of nocturnal growth hormone pulses are associated with slow-wave sleep [84, 85]. In OSAS, growth hormone secretion is decreased not only due to obesity [86-88], but also because of sleep fragmentation resulting in decreased amount of slowwave sleep [89]. In addition, repetitive hypoxaemia may affect growth hormone secretion. In animals, hypoxia inhibits growth hormone release or biosynthesis [90]. Growth hormone deficiency in adults is associated with impaired psychological well-being, insulin resistance, endothelial dysfunction, increased visceral fat, increased cardiovascular mortality and accelerated ageing $[91,92]$. Similar features are typical in OSAS, which raises the question of a possible link between OSAS-related growth hormone deficiency and the comorbidity seen in OSAS. Indeed, patients with severe OSAS have similar levels of IGF-I to adult patients with growth hormone deficiency [83]. Low IGF-I may contribute to an increased risk for cardiovascular diseases among sleep apnoeics. Vascular effects of IGF-I are endotheliumdependent [93], and endothelial cells have IGF-I receptors [94]. IGF-I increases endothelial cell nitric oxide production [95]. Nitric oxide is an important paracrine mediator of vasodilatation and inhibition of vascular smooth muscle cell growth [96].

Two recent reports suggest that growth hormone replacement therapy may also affect sleep and breathing [97, 98]. Among 145 children on growth hormone replacement, four developed sleep apnoea; in three cases this was associated with tonsillar and adenoidal hypertrophy [97]. Sleep apnoea improved in one patient after cessation of growth hormone therapy, and in all patients following tonsillectomy and adenoidectomy. In five, male, middle-aged patients with postoperative pituitary insufficiency, cessation of growth hormone replacement for 6 months resulted in a decrease of obstructive apnoeic events but in an increase of central apnoeic events [98]. Following cessation of growth hormone replacement, slow-wave sleep decreased markedly [98].

At least in theory, an unfortunate coexistence of growth hormone deficiency and SDB would result in a potentially vicious interaction between two altered physiological functions, resulting in severe anatomical abnormalities. A primary growth hormone deficiency could predispose to SDB through short stature, craniofacial growth retardation and low respiratory drive. SDB would further aggravate growth hormone deficiency through sleep disturbance. A primary SDB could aggravate itself by affecting craniofacial and upper airway soft tissue growth through induction of secondary growth hormone deficiency.

In patients with growth hormone deficiency and with predisposing anatomical abnormalities for SDB, a systematic screening for SDB is encouraged. Nasal CPAP treatment and maxillomandibular surgery are feasible therapeutical approaches in these patients. Treatment of SDB may result in normalisation of growth hormone secretion and normal growth in children [99-101]. Conversely, symptoms of SDB should also be monitored during growth hormone replacement therapy because of increased risk of SDB.

\section{Cushing's syndrome and Cushing's disease}

SHIPLEY and co-workers [22, 23] found sleep apnoea in $45 \%$ of their 22 patients with Cushing's disease or Cushing's syndrome. Long-term, high-dose corticosteroid therapy may also contribute to SDB [77]. This is of importance especially in patients with juvenile rheumatoid arthritis, whose craniofacial abnormalities (micrognathia) also predispose to SDB.

\section{Pregnancy}

Pregnancy has a marked impact on breathing, which is largely mediated through hormones. The levels of the female sex hormones, progesterone and oestrogen, increase markedly. Progesterone increases ventilation [102] and may cause hypocapnia and respiratory alkalosis, and result in respiratory instability and episodes of central apnoea during nonrapideye movement sleep [103]. Pharyngeal dimensions decrease during pregnancy [104], nasal congestion and rhinitis are frequent [105], and the enlarging uterus compromises the performance of the diaphragm. Increased oestrogen levels may cause oedema in the upper airway mucosa, and, thereby, be responsible for the upper airway symptoms [106]. Conversely, increased female hormone levels may protect the upper airway patency, assuming that upper airway dilators are capable of responding appropriately [107].

Despite marked "central obesity", neither normal [108, 109] nor multiple pregnancy [110] seems to predispose to SDB. However, in obese females pre-existing SDB may deteriorate during pregnancy [109]. In pre-eclampsia, partial upper airway obstruction during sleep is common $[111,112]$. The long periods of partial upper airway obstruction are associated with increased systemic arterial blood pressure, which can be lowered with nasal CPAP therapy [111].

Snoring is frequent among pregnant females (12-23 versus $4 \%$ in nonpregnant women) [113-115]. Snoring or OSAS during pregnancy have been suggested to cause intrauterine foetal growth restriction and lower Apgar scores at birth [113, 114, 116]. Nasal CPAP therapy also seems safe and effective during pregnancy $[111,117]$, and early intervention may improve the outcome of the mother and baby.

\section{Polycystic ovary syndrome}

A high prevalence rate of SDB in females with polycystic ovary syndrome is a recent observation [30, 31]. Previously, SDB in polycystic ovary syndrome was correlated entirely with obesity, but VGONTZAS et al. [30] showed that insulin resistance was a stronger determinant of SDB than BMI or serum testosterone levels. The AHI correlates with waist-tohip ratio and serum total and free testosterone concentrations [31]. Suspicion and verification of SDB should not be ignored when females with polycystic ovary syndrome present with compatible symptoms.

\section{Menopause}

In clinical studies, male:female ratio of OSAS is $\sim 10: 1$ [118-120]. In community-based populations, the prevalence of OSAS is higher, and the male:female ratio ranges from 2:1-4:1 [121-124]. Female hormones are thought to protect them from SDB until menopause [125]. Among females referred to the sleep clinic, $47 \%$ of the postmenopausal and $21 \%$ of the premenopausal females had sleep apnoea [126]. The observations from community-based studies on the impact of menopause on the prevalence of SDB are not consistent, 
Table 2. - Effect of sex, menopause and hormone replacement therapy on prevalence of sleep-disordered breathing (SDB)

\begin{tabular}{|c|c|c|c|c|c|}
\hline \multirow[t]{2}{*}{ Group } & \multirow[t]{2}{*}{ Sample size } & \multicolumn{4}{|c|}{ SDB $\%$} \\
\hline & & AHI $\geqslant 10+$ symptoms & $\mathrm{AHI} \geqslant 15$ & $\begin{array}{c}\text { Snoring and } \\
0<\mathrm{AHI}<15\end{array}$ & $\begin{array}{c}\text { Snoring and } \\
\text { AHI }=0\end{array}$ \\
\hline Males & 741 & 3.9 & 7.2 & 17.3 & 17.4 \\
\hline Females & 1000 & 1.2 & 2.2 & 5.4 & 10.4 \\
\hline \multicolumn{6}{|l|}{ Effect of menopause } \\
\hline Premenopause & 503 & 0.6 & 0.6 & 3.2 & 7.9 \\
\hline Postmenopause & 497 & 1.9 & 3.9 & 7.5 & 13.0 \\
\hline \multicolumn{6}{|c|}{ Effect of hormone replacement } \\
\hline Without & 314 & 2.7 & 5.5 & 9.7 & 14.8 \\
\hline With & 183 & 0.5 & 1.1 & 3.8 & 9.8 \\
\hline \multicolumn{6}{|c|}{ Mode of hormone replacement ${ }^{\#}$} \\
\hline Oestrogen & & & 1.5 & & \\
\hline Oestrogen+progestin & & & 0.3 & & \\
\hline
\end{tabular}

AHI: apnoea/hypopnoea index. In postmenopausal females without hormone replacement therapy, prevalence of sleep-disordered breathing does not differ from that of males, whereas in postmenopausal females on hormone replacement therapy, it is at the same level as that in premenopausal females. ${ }^{\#}$ : difference nonsignificant between the various modes of hormone replacement therapy. Modified from [2].

although most studies show increased prevalence estimates of sleep apnoea after menopause $[2,122,123,127]$. Much of the discrepancy could be attributed to variation in the definition of SDB. Episodes of sleep apnoea seem to grossly underestimate SDB in females, since partial upper airway obstruction is far more common. Of 62 healthy postmenopausal females, $17 \%$ had a significant amount of partial upper airway obstruction during sleep [11]. In a large community-based study, $1.9 \%$ of postmenopausal females and $0.6 \%$ of premenopausal females had OSAS, defined as an AHI of $\geqslant 10$ and occurrence of daytime symptoms [2].

Postmenopausal hormone replacement therapy (HRT) may prevent SDB. In a cross-sectional study, the prevalence estimates of sleep apnoea were almost similar in postmenopausal females without HRT than in males, whereas in HRT users they were compatible with those in premenopausal females [2] (table 2). No significant difference was found between the effect of oestrogen alone or oestrogen plus progestin users.

Short-term administration of progestin alone [128, 129] (fig. 2) or in combination with oestrogen [130, 131] has shown only slight, if any, improvement in SDB in postmenopausal females. However, it is not excluded that long-term HRT may be beneficial in terms of improving SDB. Increasing evidence

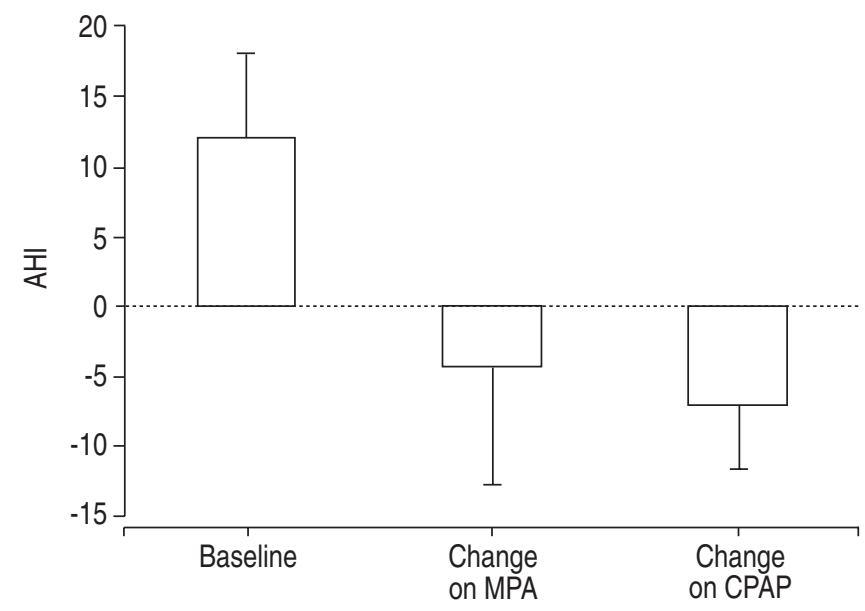

Fig. 2.-Decrease in apnoea-hypopnoea index (AHI) with a 2-week medroxyprogesterone acetate (MPA; $60 \mathrm{mg}$ daily) or with 1-night nasal continuous positive airway pressure (CPAP) treatment in six postmenopausal females. Values are expressed as median with the bars representing interquartile range. Based on data from [129]. suggests that menopause is an independent risk factor for SDB. Indeed, SDB partial obstruction, in particular, should be considered in the differential diagnostics of depression, insomnia or restless legs syndrome to explain excessive sleepiness, and fatigue among postmenopausal females.

\section{Androgens}

The male predominance of OSAS has been attributed to testosterone-mediated aggravation of SDB or to the lack of a protective effect of female hormones. Androgens do not affect oestradiol or progesterone levels but may reduce their effect by downregulating oestrogen and progesterone receptors [132]. Oestrone levels increase with androgens [132]. Among seven obese males, all except one with hypogonadism presented with sleep apnoea [133]. In males, exogenous testosterone may suppress $[134]$ or augment $[135,136]$ hypoxic respiratory responses and lead to periodic breathing and sleep apnoea [133, 135, 136]. Exogenous testosterone does not affect the upper airway dimensions in males [136].

Few studies have systemically evaluated the effects of exogenous androgen replacement therapy on SDB. Testosterone replacement therapy induced OSAS in one of five males and aggravated pre-existing SDB in another [134]. In 11 hypogonadal males, testosterone replacement increased apnoeic events but only in three subjects was the increase considered clinically significant [136]. In a placebo-controlled study of 17 elderly males with partial androgen deficiency, testosterone replacement therapy decreased total sleep time and sleep efficiency, and aggravated sleep apnoea [137].

The few available data from females with SDB support the link between androgens and SDB. Irrespective of the menopausal state, obese females have higher androgen levels than nonobese females [138, 139]. The prevalence of snoring plateaus or decreases in males after the age of $60 \mathrm{yrs}[140$, 141]. Contrary to the observations in males, females continue to increase their snoring even beyond the age of $60 \mathrm{yrs}$ [140]. Those observations suggest that decrease of androgens in ageing males alleviates snoring, whereas menopause-induced oestrogen and progesterone deficiency and increased androgenicity continue to aggravate snoring in postmenopausal females. In a lean, 70-yr-old female, a testosteroneproducing tumour caused sleep apnoea, which disappeared after removal of the tumour [142]. Exogenous testosterone induces sleep apnoea and even alters the upper airway dimensions in females [143]. 
However, it is still somewhat controversial whether testosterone contributes to the development or aggravation of SDB. In males with OSAS, androgen blockade with flutamide did not have any effects on ventilatory responses or SDB [144]. However, basal testosterone levels may be decreased in such patients and thus the therapeutic response to blockade may be lessened.

After discontinuing testosterone therapy for 2 months in haemodialysis patients, no change in AHI occurred [145]. Conversely, $75 \%$ of the patients with a clinical history of OSAS were on testosterone therapy, compared with only $35 \%$ of those without history of SDB. It is not clear whether these observations reflect the effect of testosterone per se, or possibly the severity of underlying renal disease and disturbances in the acid/base balance leading to respiratory changes.

In OSAS, both morning and nocturnal testosterone concentrations may be decreased [83, 146, 147], but increase after uvulopalatal resection [146]. There are several mechanisms in which OSAS may impair testosterone levels. First, in obesity, total testosterone is decreased and in massively obese patients the free testosterone levels may also decrease [148, 149]. Secondly, sleep apnoeics are sleep-deprived. Testosterone concentrations fall with prolonged physical stress, sleep deprivation and sleep fragmentation in normal young males [150, 151], including internal medicine residents [152]. Thirdly, repetitive episodes of hypoxaemia is typical for OSAS. Hypoxia decreases luteinising hormone $(\mathrm{LH})$ and testosterone levels and alters the circadian rhythm of testosterone secretion [7, 153, 154]. Depression of testosterone levels correlates with the severity of hypoxaemia in patients with chronic obstructive pulmonary disease (COPD) or sleep apnoea [7, 153, 154]. Testosterone levels rise with oxygen therapy in COPD [155] and with weight reduction in obesity hypoventilation syndrome [156]. Fourthly, decreased testosterone levels may be part of an adaptive homeostatic mechanism to reduce SDB assuming that testosterone aggravates SDB.

Androgen replacement therapy is likely to become more common in the treatment of andropausal symptoms in ageing males. With the availability of preparations developed specifically for females, androgen replacement therapy is also likely to become more widespread as a treatment of fatigue, decreased libido or osteoporosis in postmenopausal females [157]. Apparition of symptoms suggesting SDB should be monitored in males and in females during androgen replacement therapy.

\section{Effect of nasal continuous positive airway pressure on hormones}

Much of the current knowledge on the interactions between hormones and OSAS is based on intervention studies with nasal CPAP. Nasal CPAP is the most efficient therapy to maintain the upper airway patency during sleep. Its efficacy to control sleep apnoea and hypopnoea starts from the very first night of therapy [158]. Changes at the levels of several hormones (table 3) are interpreted to be related to SDB or associated sleep disturbance, if they consistently respond to on/off nasal CPAP interventions. Hormonal changes are potential mediators to link SDB with various comorbidities.

\section{Diabetes}

Among morbidly obese (average BMI $42.7 \mathrm{~kg} \cdot \mathrm{m}^{-2}$ ) patients with sleep apnoea and type- 2 diabetes, nasal CPAP treatment for 4 months improved insulin responsiveness [168]. The study population was highly selected, and therefore these results cannot be extrapolated to all type- 2 diabetics. Another study
Table 3.-Various hormones in obstructive sleep apnoea syndrome (OSAS) and the effect of nasal continuous positive airway pressure (CPAP) therapy on hormones

\begin{tabular}{lccc}
\hline Hormone & OSAS & $\begin{array}{c}\text { Effect of } \\
\text { nasal CPAP }\end{array}$ & Reference \\
\hline Growth hormone & $\downarrow$ & $\uparrow$ & {$[83,159,160]$} \\
IGF-I & $\downarrow$ & $\uparrow$ & {$[83]$} \\
TSH & $\downarrow$ or $\leftrightarrow$ & $\downarrow$ & {$[55]$} \\
Leptin & $\uparrow$ & $\downarrow$ & {$[33]$} \\
& & & {$[34]$} \\
Noradrenaline & $\uparrow$ or $\leftrightarrow$ & $\downarrow$ or $\leftrightarrow$ & {$[55,160,162]$} \\
Cortisol & $\uparrow$ & $\leftrightarrow$ & {$[55,83,162]$} \\
Aldosterone & $?$ & $\uparrow$ or $\downarrow$ & {$[161,163]$} \\
Renin & $?$ & $\uparrow$ & {$[161]$} \\
ANP & $\uparrow$ & $\downarrow$ & {$[164,165]$} \\
LH & $\downarrow$ or $\leftrightarrow$ & $?$ & {$[55,83,147]$} \\
Testosterone & $\downarrow$ or $\leftrightarrow$ & $\uparrow$ or $\leftrightarrow$ & {$[55,83,146,147]$} \\
Prolactin & $\leftrightarrow$ & $\downarrow$ or $\leftrightarrow$ & {$[55,83,166]$} \\
Substance P & $\uparrow$ & $?$ & {$[167]$} \\
\hline
\end{tabular}

IGF-I: insulin-like growth factor-I; TSH: thyroid-stimulating hormone (thyrotropin); ANP: atrial natriuretic peptide; LH: luteinising hormone; $\uparrow:$ increased; $\downarrow:$ decreased; $\leftrightarrow$ : no change.

in sleep apnoeics found no effect of a 2-month nasal CPAP therapy on glucose and insulin metabolism [169]. The duration of nasal CPAP therapy was only for 2 months, and thus it cannot be excluded that a longer treatment would improve glucose tolerance.

\section{Leptin}

Serum leptin levels decrease with nasal CPAP therapy [33-35] (fig. 3) without weight loss [34, 35]. The decrease in leptin levels is already observed after the first night on nasal CPAP [170]. Nasal CPAP does not affect the secretory profile of leptin. The nocturnal increase in serum leptin levels is observed both on and off nasal CPAP [170]. CPAP-induced reduction in leptin level is likely due to both improved sleep and breathing. Nasal CPAP therapy increases slow-wave sleep and increases growth hormone secretion [160, 162, 171], which in turn inhibits leptin secretion [172, 173]. While normalising nocturnal breathing, hypoxic and hypercapnic stimuli may no longer increase leptin secretion [44, 174-177]. These findings suggest that nasal CPAP therapy either improves the leptin resistance in obese patients, or with improved

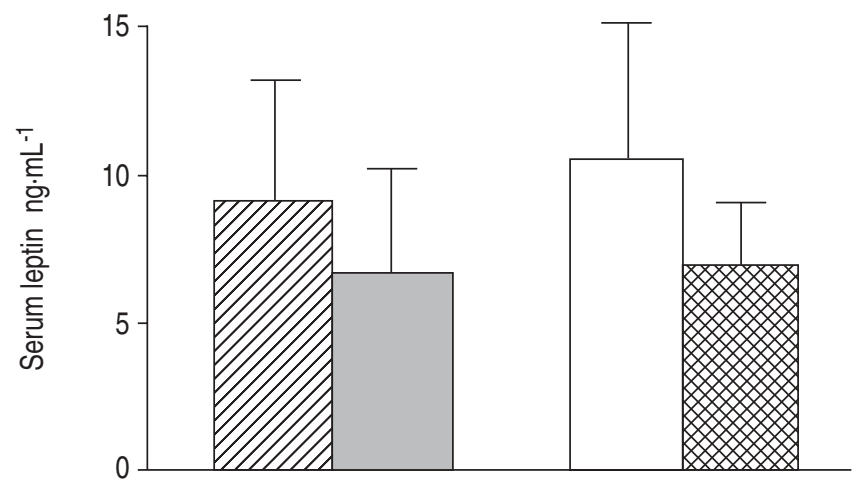

Fig. 3.-Serum leptin levels in 30 patients with obstructive sleep apnoea syndrome (OSAS; $\mathbb{Z})$ and in 30 matched controls $(\square)$. The effects of 6-month nasal CPAP treatment on OSAS patients is also shown. Pre-CPAP: $\square$; Post-CPAP: $\mathbf{D}$. Reproduced from [35] with permission. 
ventilation, less leptin is needed to stimulate breathing. It is also possible that nasal CPAP therapy, by normalising sleep structure and growth hormone secretion, may in turn normalise leptin. Moreover, by reducing leptin levels, nasal CPAP therapy is likely to decrease the comorbidity related to OSAS.

\section{Catecholamines}

In most studies, nasal CPAP treatment decreases plasma or urinary noradrenaline levels, whereas adrenaline levels in most cases remain unchanged [55, 178, 179]. In contrast, in noninsulin-dependent diabetics with OSAS, neither fasting adrenaline nor noradrenaline levels change on CPAP [169].

\section{Thyrotrophin}

Although the prevalence of hypothyroidism is not essentially increased, thyrotrophin (TSH) levels may be low in OSAS. In male patients with OSAS, the decrease in serum TSH was most pronounced in patients with the most severe pretreatment nocturnal hypoxaemia. The response to TSHreleasing hormone challenge was normal before and after treatment and was not affected by CPAP treatment [55]. However, TSH levels decreased even further after 7 months of CPAP therapy [55].

\section{Growth hormone and insulin-like growth factor-I}

Nasal CPAP therapy increases slow-wave sleep and normalises growth hormone secretion without changes in body weight $[160,162,171]$ (fig. 4). Increases in IGF-I concentrations with CPAP [83] are most probably mediated via increased growth hormone secretion. However, the possible effects of improved nocturnal breathing on growth hormone release cannot be excluded [90]. Increased production of IGF-I [83] and circulating nitric oxide [180] are plausible mediators of the beneficial effect of nasal CPAP on cardiovascular disorders.

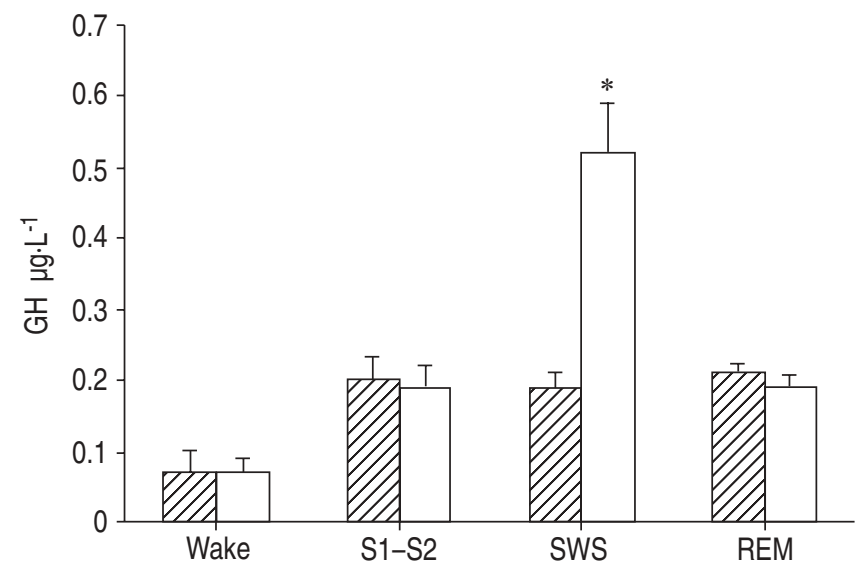

Fig. 4.- Plasma growth hormone (GH) levels measured with frequent sampling during different sleep stages in eight patients with severe obstructive sleep apnoea syndrome (OSAS) before $(\mathbb{Z})$ and after $(\square)$ nasal continuous positive airway pressure (CPAP) treatment. The relationship between slow-wave sleep (SWS) and GH concentrations becomes significant on CPAP treatment. Wake: stage wake; S1-S2: sleep stage 1-2; REM: rapid-eye movement sleep. Reproduced from [171] with permission.

\section{Testosterone}

Both LH and testosterone secretion increase during sleep $[181,182]$. In young healthy males, there is a sleep-controlled rise in serum testosterone concentration that is linked with the first rapid-eye movement sleep period [183]. Since CPAP therapy improves sleep quality, it is also logical that the decreased testosterone levels [83, 146, 147] are normalised on nasal CPAP therapy $[83,146]$.

\section{Conclusions}

Sleep-disordered breathing is still underdiagnosed [184], also when appearing in connection with hormone disorders. There are complex interactions between hormones and sleepdisordered breathing. Nasal continuous positive airway pressure is currently the treatment of choice in mild-to-severe obstructive sleep apnoea $[158,185]$, but expanding understanding of hormone interactions could provide the tools for powerful alternative therapeutic approaches. Sleep apnoea brings together pulmonologists, endocrinologists, paediatricians, gynaecologists, epidemiologists and many other specialists to combat the sleep apnoea epidemic.

\section{References}

1. Young T, Palta M, Dempsey J, Skatrud J, Webber S, Badr S. The occurrence of sleep-disordered breathing among middleaged adults. $N$ Engl J Med 1993; 328: 1230-1235.

2. Bixler EO, Vgontzas AN, Lin H-M, et al. Prevalence of sleep-disordered breathing in women: effects of gender. Am J Respir Crit Care Med 2001; 163: 608-613.

3. Van Cauter E. Endocrine physiology. In: Kryger $\mathrm{MH}$, Roth T, Dement WC, eds. Principles and Practise of Sleep Medicine. New York, W.B. Saunders Co., 2000; pp. 266-278.

4. Saaresranta T, Polo O. Hormones and breathing. Chest 2002; 122: 2165-2182.

5. Späth-Schwalbe E, Gofferje M, Kern W, Born J, Fehm HL Sleep disruption alters nocturnal ACTH and cortisol secretory patterns. Biol Psychiatry 1991; 29: 575-584.

6. Pastuszko A, Wilson DF, Ericinsk M. Neurotransmitter metabolism in rat brain synaptosomes: effect of anoxia and pH. J Neurochem 1982; 38: 1657-1667.

7. Semple PD, Beastall GH, Watson WS, Hume R. Hypothalamicpituitary dysfunction in respiratory hypoxia. Thorax 1981; 36: 605-609.

8. Raff H, Roarty TP. Renin, ACTH, and aldosterone during acute hypercapnia and hypoxia in conscious rats. $A m J$ Physiol 1988; 254: R431-R435.

9. Raff H, Shinsako J, Keil LC, Dallman MF. Vasopressin, $\mathrm{ACTH}$, and corticosteroids during hypercapnia and graded hypoxia in dogs. Am J Physiol 1983; 244: E453-E458.

10. Young T, Peppard PE, Gottlieb DJ. Epidemiology of obstructive sleep apnea: a population health perspective. Am J Respir Crit Care Med 2002; 165: 1217-1239.

11. Polo-Kantola P, Rauhala E, Helenius H, Erkkola R, Irjala $\mathrm{K}$, Polo $\mathrm{O}$. Breathing during sleep in menopause: a randomized, controlled, cross-over trial with estrogen therapy. Obstet Gynecol 2003; (in press).

12. Hart TB, Radow SK, Blackard WG, Tucker HS, Cooper KR. Sleep apnea in acromegaly. Arch Intern Med 1985; 145: 865866.

13. Pekkarinen T, Partinen M, Pelkonen R, Iivanainen M. Sleep apnoea and daytime sleepiness in acromegaly: relationship to endocrinological factors. Clin Endocrinol 1987; 27: 649-654.

14. Grunstein R, Kian KY, Sullivan CE. Sleep apnea in acromegaly. Ann Intern Med 1991; 115: 527-532.

15. Pelttari L, Polo O, Rauhala E, et al. Nocturnal breathing 
abnormalities in acromegaly after adenomectomy. Clin Endocrinol 1995; 43: 175-182.

16. Rosenow F, Reuter S, Deuss U, et al. Sleep apnoea in treated acromegaly: relative frequency and predisposing factors. Clin Endocrinol 1996; 45: 563-569.

17. Weiss V, Sonka K, Pretl M, et al. Prevalence of the sleep apnea syndrome in acromegaly population. $J$ Endocrinol Invest 2000; 23: 515-519.

18. Rajagopal KR, Abbrecht PH, Derderian SS, et al. Obstructive sleep apnea in hypothyroidism. Ann Intern Med 1984; 101: 491-494.

19. Grunstein RR, Sullivan CE. Sleep apnea and hypothyroidism: mechanisms and management. Am J Med 1988; 85: 775-779.

20. Lin C-C, Tsan K-W, Chen P-J. The relationship between sleep apnea syndrome and hypothyroidism. Chest 1992; 102: 1663-1667.

21. Pelttari L, Rauhala E, Polo O, et al. Upper airway obstruction in hypothyroidism. J Intern Med 1994; 236: 177-181.

22. Shipley JE, Schteingart DE, Tandon R, Starkman MN. Sleep architecture and sleep apnea in patients with Cushing's disease. Sleep 1992; 15: 514-518.

23. Shipley JE, Schteingart DE, Tandon R, et al. EEG sleep in Cushing disease and Cushing syndrome: comparison with patients with major depressive disorder. Biol Psychiatry 1992; 32: 146-155.

24. Rees PJ, Prior JG, Cochrane GM, Clark TJ. Sleep apnoea in diabetic patients with autonomic neuropathy. $J R$ Soc Med 1981; 74: 192-195.

25. Mondini S, Guilleminault C. Abnormal breathing patterns during sleep in diabetes. Ann Neurol 1985; 17: 391-395.

26. Katsumata K, Okada T, Miyao M, Katsumata Y. High incidence of sleep apnea syndrome in a male diabetic population. Diabetes Res Clin Pract 1991; 13: 45-51.

27. Elmasry A, Lindberg E, Berne C, et al. Sleep-disordered breathing and glucose metabolism in hypertensive men: a population-based study. J Intern Med 2001; 249: 153-161.

28. Catterall JR, Calverley PMA, Ewing DJ, Shapiro CM, Clarke BF, Douglas NJ. Breathing, sleep, and diabetic autonomic neuropathy. Diabetes 1984; 33: 1025-1027.

29. Ficker JH, Dertinger SH, Siegfried W, et al. Obstructive sleep apnoea and diabetes mellitus: the role of cardiovascular autonomic neuropathy. Eur Respir J 1998; 11: 14-19.

30. Vgontzas AN, Legro RS, Bixler EO, Grayev A, Kales A, Chrousos P. Polycystic ovary syndrome is associated with obstructive sleep apnea and daytime sleepiness: role of insulin resistance. J Clin Endocrinol Metab 2001; 86: 517520.

31. Fogel RB, Malhotra A, Pillar G, Pittman SD, Dunaif A, White DP. Increased prevalence of obstructive sleep apnea syndrome in obese women with polycystic ovary syndrome. $J$ Clin Endocrinol Metab 2001; 86: 1175-1180.

32. Vgontzas AN, Papanicolaou DA, Bixler EO, et al. Sleep apnea and daytime sleepiness and fatigue: relation to visceral obesity, insulin resistance, and hypercytokinemia. $J$ Clin Endocrinol Metab 2000; 85: 1151-1158.

33. Saarelainen S, Lahtela J, Kallonen E. Effect of nasal CPAP treatment on insulin sensitivity and plasma leptin. J Sleep Res 1997; 6: 146-147.

34. Chin K, Shimizu K, Nakamura T, et al. Changes in intraabdominal visceral fat and serum leptin levels in patients with obstructive sleep apnea syndrome following nasal continuous positive airway pressure therapy. Circulation 1999; 100: 706-712.

35. Ip MS, Lam KSL, Ho C, Tsang KWT, Lam W. Serum leptin and vascular risk factors in obstructive sleep apnea. Chest 2000; 118: 580-586.

36. Ip MSM, Lam B, Ng MMT, Lam WK, Tsang KWT, Lam KSL. Obstructive sleep apnea is independently associated with insulin resistance. Am J Respir Crit Care Med 2002; 165: 670-676.

37. Punjabi NM, Sorkin JD, Katzel LI, Goldberg AP, Schwartz
AR, Smith PL. Sleep-disordered breathing and insulin resistance in middle-aged and overweight men. Am J Respir Crit Care Med 2002; 165: 677-682.

38. Spiegel K, Leproult R, Van Cauter E. Impact of sleep debt on metabolic and endocrine function. Lancet 1999; 354: 1435-1439.

39. Tiihonen $\mathbf{M}$, Partinen $\mathbf{M}$, Närvänen S. The severity of obstructive sleep apnoea is associated with insulin resistance. J Sleep Res 1993; 2: 56-61.

40. Villa P, Multari G, Montesano M, et al. Sleep apnoea in children with diabetes mellitus: effect of glycaemic control. Diabetologia 2000; 43: 696-702.

41. Elmasry A, Janson C, Lindberg E, Gislason T, Tageldin MA, Boman G. The role of habitual snoring and obesity in the development of diabetes: a 10-year follow-up study in a male population. J Intern Med 2000; 248: 13-20.

42. O'Donnell CP, Schaub CD, Haines AS, et al. Leptin prevents respiratory depression in obesity. Am $J$ Respir Crit Care Med 1999; 159: 1477-1484.

43. Phillips BG, Kato M, Narkiewicz K, Choe I, Somers VK. Increases in leptin levels, sympathetic drive, and weight gain in obstructive sleep apnea. Am J Physiol Heart Circ Physiol 2000; 279: H234-H237.

44. Phipps PR, Starritt E, Caterson I, Grunstein RR. Association of serum leptin with hypoventilation in human obesity. Thorax 2002; 57: 75-76.

45. Wallace AM, McMahon AD, Packard CJ, et al. Plasma leptin and risk of cardiovascular disease in the West of Scotland Coronary Prevention Study (WOSCOPS). Circulation 2001; 104: 3052-3056.

46. Segal KR, Landt M, Klein S. Relationship between insulin sensitivity and plasma leptin concentration in lean and obese men. Diabetes 1996; 45: 988-991.

47. Söderberg S, Olsson T, Eliasson M, Johnson O, Ahren B. Plasma leptin levels are associated with abnormal fibrinolysis in men and postmenopausal women. J Intern Med 1999; 245: 533-543.

48. Chessler SD, Fujimoto WY, Shofer JB, Boyko EJ, Weigle DS. Increased plasma leptin levels are associated with fat accumulation in Japanese Americans. Diabetes 1998; 47: 239-243.

49. McNeely MJ, Boyko EJ, Weigle DS, et al. Association between baseline plasma leptin levels and subsequent development of diabetes in Japanese Americans. Diabetes Care 1999; 22: 65-70.

50. Narkiewicz K, Kato M, Pesek CA, Somers VK. Human obesity is characterized by a selective potentiation of central chemoreflex sensitivity. Hypertension 1999; 33: 1153-1158.

51. Somers VK, Dyken ME, Clary MP, Abboud FM. Sympathetic neural mechanisms in obstructive sleep apnea. J Clin Invest 1995; 96: 1897-1904.

52. Narkiewicz K, van de Borne PJH, Pesek CA, Dyken ME, Montano N, Somers VK. Selective potentiation of peripheral chemoreflex sensitivity in obstructive sleep apnea. Circulation 1999; 99: 1183-1189.

53. Somers VK, Mark AL, Zalava DC, Abboud FM. Contrasting effects of hypoxia and hypercapnia on ventilatory and sympathetic activity in humans. J Appl Physiol 1989; 67: 2101-2106.

54. Eisenberg E, Zimlichman R, Lavie P. Plasma norepinephrine levels in patients with sleep apnea syndrome. $N$ Engl J Med 1990; 322: 932-933.

55. Bratel T, Wennlund A, Carlström K. Pituitary reactivity, androgens and catecholamines in obstructive sleep apnoea. Effects of continuous positive airway pressure treatment (CPAP). Respir Med 1999; 93: 1-7.

56. Irwin M, Thompson J, Miller C, Gillin JC, Ziegler M. Effects of sleep and sleep deprivation on catecholamine and interleukin-2 levels in humans: clinical implications. J Clin Endocrinol Metab 1999; 84: 1979-1985.

57. Hedner J, Darpo B, Ejnell H, Carlson J, Caidahl K. Reduction in sympathetic activity after long-term CPAP 
treatment in sleep apnoea: cardiovascular implications. Eur Respir J 1995; 8: 222-229.

58. Coy TV, Dimsdale JE, Ancoli-Israel S, Clausen J. Sleep apnoea and sympathetic nervous system activity: a review. J Sleep Res 1996; 5: 42-50.

59. Zwillich CW, Pierson DJ, Hofeldt FD, Lufkin EG, Weil JV. Ventilatory control in myxedema and hypothyroidism. $N$ Engl $J$ Med 1975; 292: 662-665.

60. Parving HH, Hansen JM, Nielsen SL, Rossing N, Munck O, Lassen NA. Mechanisms of edema formation in myxedemaincreased protein extravasation and relatively slow lymphatic drainage. $N$ Engl J Med 1979; 301: 460-465.

61. Orr WC, Males JL, Imes NK. Myxedema and obstructive sleep apnea. Am J Med 1981; 70: 1061-1066.

62. Millman RP, Bevilacqua J, Peterson DD, Pack AI. Central sleep apnea in hypothyroidism. Ann Rev Respir Dis 1983; 127: 504-507.

63. Grunstein R. Obstructive sleep apnea syndrome and hypothyroidism. Chest 1994; 105: 1296-1297.

64. Meslier N, Giraud P, Person C, Badatcheff A, Racineux JL. Prevalence of hypothyroidism in sleep apnoea syndrome. Eur J Med 1992; 1: 437-438.

65. Winkelmann JW, Goldman H, Piscatelli N, Lukas SE, Dorsey CM, Cunningham S. Are thyroid function tests necessary in patients with suspected sleep apnea? Sleep 1996; 19: 790-793

66. Roxburgh F, Collis A. Notes on a case of acromegaly. BMJ 1896; 63-65.

67. Guilleminault C, Cummiskey J, Dement WC. Sleep apnea syndrome: recent advances. Adv Intern Med 1980; 26: 347372.

68. Guilleminault C, Simmons FB, Motta J, et al. Obstructive sleep apnea syndrome and tracheostomy. Long-term followup experience. Arch Intern Med 1981; 141: 985-988.

69. Cadieux RJ, Kales A, Santen RJ, Bixler EO, Gordon R. Endoscopic findings in sleep apnea associated with acromegaly. J Clin Endocrinol Metab 1982; 55: 18-22.

70. Mezon BJ, West P, MacClean J, Kryger M. Sleep apnea in acromegaly. Am J Med 1980; 69: 615-618.

71. Grunstein RR, Ho KY, Berthon-Jones M, Stewart D, Sullivan CE. Central sleep apnea is associated with increased ventilatory response to carbon dioxide and hypersecretion of growth hormone in patients with acromegaly. Am J Respir Crit Care Med 1994; 150: 496-502.

72. Rosenow F, Reuter S, Szelies B, et al. Sleep apnoea in acromegaly - prevalence, pathogenesis and therapy. Presse Med 1994; 23: 1203-1208.

73. Ip MS, Tan KC, Peh WC, Lam KS. Effect of Sandostatin LAR on sleep apnoea in acromegaly: correlation with computerized tomographic cephalometry and hormonal activity. Clin Endocrinol 2001; 55: 477-483.

74. Perks WH, Horrocks PM, Cooper RA, Bradbury S, Allen A, Baldock N. Sleep apnea in acromegaly. BMJ 1980; 280: 894 897.

75. Chanson P, Timsit J, Benoit O, et al. Rapid improvement in sleep apnoea of acromegaly after short-term treatment with somatostatin analogue SMS 201-995. Lancet 1986; 2: 12701271.

76. Leibowitz G, Shapiro MS, Salameh M, Glaser B. Improvement of sleep apnoea due to acromegaly during short-term treatment with octreotide. J Intern Med 1994; 236: 231-235.

77. Rosenow F, McCarthy V, Caruso AC. Sleep apnoea in endocrine diseases. J Sleep Res 1998; 7: 3-11.

78. Mickelson SA, Rosenthal LD, Rock JP, Senior BA, Friduss ME. Obstructive sleep apnea syndrome and acromegaly. Otolaryngol Head Neck Surg 1994; 111: 25-30.

79. Dagan Y, Abadi J, Lifschitz A, Laron Z. Severe obstructive sleep apnoea syndrome in an adult patient with Laron syndrome. Growth Horm IGF Res 2001; 11: 247-249.

80. Orliaguet O, Pepin JL, Bettega G, Ferretti G, Mignotte HN, Levy P. Sleep apnoea and Turner's syndrome. Eur Respir J 2001; 17: 153-155.
81. Partsch CJ, Lammer C, Gillessen-Kaesbach G, Pankau R. Adult patients with Prader-Willi syndrome: clinical characteristics, life circumstances and growth hormone secretion. Growth Horm IGF Res 2000; 10: Suppl. B, S81-S85.

82. Hertz G, Cataletto M, Feinsilver SH, Angulo M. Sleep and breathing patterns in patients with Prader Willi syndrome (PWS): effects of age and gender. Sleep 1993; 16: 366-371.

83. Grunstein RR, Handelsman DJ, Lawrence SJ, Blackwell C, Caterson ID, Sullivan CE. Neuroendocrine dysfunction in sleep apnea: reversal by continuous positive airways pressure therapy. J Clin Endocrinol Metab 1989; 68: 352-358.

84. Van Cauter E, Caufriez A, Kerkhofs M, van Onderbergen A, Thorner MO, Copinschi G. Sleep, awakenings, and insulinlike growth factor-I modulate the growth hormone $(\mathrm{GH})$ secretory response to GH-releasing hormone. J Clin Endocrinol Metab 1992; 74: 1451-1459.

85. Van Cauter E, Kerkhofs M, Caufriez A, van Onderbergen A, Thorner MO, Copinschi G. A quantitative estimation of growth hormone secretion in normal man: reproducibility and relation to sleep and time of day. $J$ Clin Endocrinol Metab 1992; 74: 1441-1450.

86. Veldhuis JD, Iranmanesh A, Ho KK, Waters MJ, Johnson ML, Lizarralde G. Dual effects in pulsatile growth hormone secretion and clearance subserve the hyposomatotropism of obesity in man. J Clin Endocrinol Metab 1991; 72: 51-59.

87. Gianotti L, Pivetti S, Lanfranco F, et al. Concomitant impairment of growth hormone secretion and peripheral sensitivity in obese patients with obstructive sleep apnea syndrome. J Clin Endocrinol Metab 2002; 87: 5052-5057.

88. Scacchi M, Pincelli AI, Cavagnini F. Growth hormone in obesity. Int J Obes Relat Metab Disord 1999; 23: 260-271.

89. Issa FG, Sullivan CE. The immediate effects of nasal continuous positive airway pressure treatment on sleep pattern in patients with obstructive sleep apnea syndrome. Electroencephalogr Clin Neurophysiol 1986; 63: 10-17.

90. Zhang Y-S, Du J-Z. The response of growth hormone and prolactin of rats to hypoxia. Neurosci Lett 2000; 279: 137140.

91. Veldhuis JD, Iranmanesh A. Physiological regulation of the human growth hormone $(\mathrm{GH})$-insulin-like growth factor type I (IGF-I) axis: predominant impact of age, obesity, gonadal function, and sleep. Sleep 1996; 19: S221-S224.

92. Conceicao FL, Bojensen A, Jorgensen JOL, Christiansen JS. Growth hormone therapy in adults. Front Neuroendocrinol 2001; 22: 213-246.

93. Wu H, Jeng YY, Yue C, Chyu KY, Hsueh WA, Chan TM. Endothelial-dependent vascular effects of insulin and insulinlike growth factor I in the perfused rat mesenteric artery and aortic ring. Diabetes 1994; 43: 1027-1032.

94. Bar RS, Boes M, Dake BL, Booth BA, Henley SA, Sandra A. Insulin, insulin-like growth factors, and vascular endothelium. Am J Med 1988; 85: Suppl. 5a, 59-70.

95. Tsukahara H, Gordienko DV, Tonshoff B, Gelato MC, Goligorsky MS. Direct demonstration of insulin-like growth factor-I-induced nitric oxide production by endothelial cells. Kidney Int 1994; 45: 598-604.

96. Radomski MW, Salas E. Nitric-oxide biological mediator, modulator and factor of injury: its role in the pathogenesis of atherosclerosis. Atherosclerosis Suppl 1995; 118: S69-S80.

97. Gerard JM, Garibaldi L, Myers SE, et al. Sleep apnea in patients receiving growth hormone. Clin Ped 1997; 36: 321326.

98. Nolte W, Radisch C, Rodenbeck A, Wiltfang J, Hufner M. Polysomnographic findings in five adult patients with pituitary insufficiency before and after cessation of human growth hormone replacement therapy. Clin Endocrinol 2002; 56: 805-810.

99. Waters KA, Kirjavainen $\mathrm{T}$, Jimenez $\mathrm{M}$, Cowell CT, Sillence DO, Sullivan CE. Overnight growth hormone secretion in achondroplacia: deconvolution analysis, correlation with sleep state, and changes after treatment of obstructive sleep apnea. Pediatr Res 1996; 39: 547-553. 
100. Goldstein SJ, Shprintzen RJ, Wu RH, et al. Achondroplasia and obstructive sleep apnea: correction of apnea and abnormal sleep-entrained growth hormone release by tracheostomy. Birth Defects Orig Artic Ser 1985; 21: 93-101.

101. Nieminen P, Löppönen T, Tolonen U, Lanning P, Knip M, Löppönen H. Growth and biochemical markers of growth in children with snoring and obstructive sleep apnea. Pediatrics 2002; 109: e55.

102. White DP, Douglas NJ, Pickett CK, Weil JV, Zwillich CW. Sexual influence on the control of breathing. J Appl Physiol 1983; 54: 874-879.

103. Skatrud JB, Dempsey JA. Interaction of sleep state and chemical stimuli in sustaining rhythmic ventilation. $J$ Appl Physiol 1983; 55: 813-822.

104. Pilkington S, Carli F, Dakin MJ, et al. Increase in Mallampati score during pregnancy. Br J Anaesth 1995; 74: 638-642.

105. Bende $\mathbf{M}$, Gredmark T. Nasal stuffiness during pregnancy. Laryngoscope 1999; 109: 1108-1110.

106. Mabry RL. Rhinitis of pregnancy. South Med J 1986; 79: 965-971.

107. Saaresranta T, Aittokallio T, Polo-Kantola P, Helenius H, Polo O. Effect of medroxyprogesterone on inspiratory flow shapes during sleep in postmenopausal women. Respir Physiol Neurobiol 2003; 134: 131-143.

108. Brownell LG, West P, Kryger MH. Breathing during sleep in normal pregnant women. Am Rev Respir Dis 1986; 133: 3841.

109. Maasilta P, Bachour A, Teramo K, Polo O, Laitinen LA. Sleep-related disordered breathing during pregnancy in obese women. Chest 2001; 120: 1448-1454.

110. Nikkola E, Ekblad U, Ekholm E, Mikola H, Polo O. Sleep in multiple pregnancy: breathing patterns, oxygenation, and periodic leg movements. Am J Obstet Gynecol 1996; 174: $1622-1625$.

111. Edwards N, Blyton DM, Kirjavainen TT, Sullivan CE. Hemodynamic responses to obstructive respiratory events during sleep are augmented in women with preeclampsia. Am J Hypertens 2001; 14: 1090-1095.

112. Connolly G, Razak AR, Hayanga A, Russell A, McKena P, McNicholas WT. Inspiratory flow limitation during sleep in pre-eclampsia: comparison with normal pregnant women. Eur Respir J 2001; 18: 672-676.

113. Loube DI, Poceta JS, Morales MC, Peacock MMD, Mitler MM. Self-reported snoring in pregnancy. Association with fetal outcome. Chest 1996; 109: 885-889.

114. Franklin KA, Holmgren P, Jonsson F, Poromaa N, Stenlund H, Svanborg E. Snoring, pregnancy-induced hypertension, and growth retardation of the fetus. Chest 2000; 117: 137-141.

115. Guilleminault C, Querra-Salva M-A, Chwdhuri S, Poyares D. Normal pregnancy, daytime sleeping, snoring and blood pressure. Sleep Med 2000; 1: 289-297.

116. Lefcourt LA, Rodis JF. Obstructive sleep apnea in pregnancy. Obstet Gynecol Survey 1996; 51: 503-506.

117. Polo O, Ekholm E. Nocturnal hyperventilation in pregnancy - reversal with nasal continuous positive airway pressure. Am J Obstet Gynecol 1995; 173: 238-239.

118. Block AJ, Boysen PG, Wynne JW, Hunt LA. Sleep apnea, hypopnea and oxygen desaturation in normal subjects. A strong male predominance. N Engl J Med 1979; 300: 513517.

119. Guilleminault C, Quera-Salva MA, Partinen M, Jamieson A. Women and the obstructive sleep apnea syndrome. Chest 1988; 93: 104-109.

120. Vgontzas AN, Tan TL, Bixler EO, Martin LF, Shubert D, Kales A. Sleep apnea and sleep disruption in obese patients. Arch Intern Med 1994; 154: 1705-1711.

121. Young T, Palta M, Dempsey J, Skatrud J, Weber S, Badr S. The occurrence of sleep-disordered breathing among middleaged adults. $N$ Engl J Med 1993; 328: 1230-1235.

122. Redline S, Kump K, Tishler PV, Browner I, Ferrette V.
Gender differences in sleep disordered breathing in a community-based sample. Am J Respir Crit Care Med 1994; 149: 722-726.

123. Kripke DF, Ancoli-Israel S, Klauber MR, Wingard DL, Mason WJ, Mullaney DJ. Prevalence of sleep-disordered breathing in ages 40-64 yr: a population-based survey. Sleep 1997; 20: 65-76.

124. Olson LG, King MT, Hensley MJ, Saunders NA. A community study of snoring and sleep-disordered breathing: prevalence. Am J Respir Crit Care Med 1995; 152: 711-716.

125. Block AJ, Wynne JW, Boysen PG. Sleep-disordered breathing and nocturnal oxygen desaturation in postmenopausal women. Am J Med 1980; 69: 75-79.

126. Dancey DR, Hanly PJ, Soong C, Lee B, Hoffstein V. Impact of menopause on the prevalence and severity of sleep apnea. Chest 2001; 120: 151-155.

127. Gislason T, Benediktsdottir B, Björnsson JK, Kjartansson G, Kjeld M, Kristbjarnarson H. Snoring, hypertension, and the sleep apnea syndrome. An epidemiologic study of middle-aged women. Chest 1993; 103: 1147-1151.

128. Collop NA. Medroxyprogesterone acetate and ethanolinduced exacerbation of obstructive sleep apnea. Chest 1994; 106: 792-799.

129. Saaresranta T, Polo-Kantola P, Rauhala E, Polo O. Medroxyprogesterone in postmenopausal females with partial upper airway obstruction during sleep. Eur Respir $J$ 2001; 18: 989-995.

130. Cistulli PA, Barnes DJ, Grunstein RR, Sullivan CE. Effect of short term hormone replacement in the treatment of obstructive sleep apnoea in postmenopausal women. Thorax 1994; 49: 699-702.

131. Keefe DL, Watson R, Naftolin F. Hormone replacement therapy may alleviate sleep apnea in menopausal women: a pilot study. Menopause 1999; 6: 196-200.

132. Poulin R, Simard J, Labrie C, et al. Down-regulation of estrogen receptors by androgens in the ZR-75-1 human breast cancer cell line. Endocrinology 1989; 125: 392-399.

133. Harman E, Wynne JW, Block AJ, Malloy-Fisher L. Sleepdisordered breathing and oxygen desaturation in obese patients. Chest 1981; 79: 256-260.

134. Matsumoto AM, Sandblom RE, Schoene RB, et al. Testosterone replacement in hypogonadal men: effects on obstructive sleep apnoea, respiratory drives, and sleep. Clin Endocrinol 1985; 22: 713-721.

135. Sandblom R, Matsumoto A, Schoene R, et al. Obstructive sleep apnea syndrome induced by testosterone administration. N Engl J Med 1983; 308: 508-510.

136. Schneider BK, Pickett CK, Zwillich CW, et al. Influence of testosterone on breathing during sleep. J Appl Physiol 1986; 61: 618-623.

137. Yee B, Liu PY, Yang Q, Wishart SM, Handelsman DJ, Grunstein R. A double blind, placebo controlled randomized crossover study of intramuscular testosterone esters on sleep in men over 60 years of age. J Sleep Res 2002; 11: Suppl. 1, 254.

138. Mantzoros CS, Georgiadis EI, Evangelopoulou K, Katsilambros N. Dehydroepiandrosterone sulfate and testosterone are independently associated with body fat distribution in premenopausal women. Epidemiology 1996; 7: 513-516.

139. Goodman-Gruen D, Barrett-Connor E. Total but not bioavailable testosterone is a predictor of central adiposity in postmenopausal women. Int J Obes Relat Metab Disord 1995; 19: 293-298

140. Koskenvuo M, Partinen M, Kaprio J. Snoring and disease. Ann Clin Res 1985; 17: 247-251.

141. Lindberg E, Taube A, Janson C, Gislason T, Svardsudd K, Boman G. A 10-year follow-up of snoring in men. Chest 1998; 114: 1048-1055.

142. Dexter DD, Dovre EJ. Obstructive sleep apnea due to endogenous testosterone production in a woman. Mayo Clin Proc 1998; 73: 246-248.

143. Johnson MW, Anch AM, Remmers JE. Induction of the 
obstructive sleep apnea syndrome in woman by exogenous androgen administration. Am Rev Respir Dis 1984; 129: 1023-1025.

144. Stewart DA, Grunstein RR, Berthon-Jones M, Handelsman DJ, Sullivan CE. Androgen blockade does not affect sleepdisordered breathing or chemosensitivity in men with obstructive sleep apnea. Am Rev Respir Dis 1992; 146: 1389-1393.

145. Millman RP, Kimmel PL, Shore ET, Wasserstein AG. Sleep apnea in hemodialysis patients: the lack of testosterone effect on its pathogenesis. Nephron 1985; 40: 407-410.

146. Santamaria JD, Prior JC, Fleetham JA. Reversible reproductive dysfunction in men with obstructive sleep apnoea. Clin Endocrinol 1988; 28: 461-470.

147. Luboshitzky R, Aviv A, Hefetz A, et al. Decreased pituitarygonadal secretion in men with obstructive sleep apnea. J Clin Endocrinol Metab 2002; 87: 3394-3398.

148. Glass AR. Endocrine aspects of obesity. Med Clin North Am 1989; 73: 139-160.

149. Lima N, Cavaliere H, Knobel M, Halpern A, Medeiros-Neto G. Decreased androgen levels in massively obese men may be associated with impaired function of the gonadostat. Int $J$ Obes Relat Metab Disord 2000; 24: 1433-1437.

150. Elman I, Breier A. Effects of acute metabolic stress on plasma progesterone and testosterone in male subjects: relationship to pituitary-adrenocortical axis activation. Life Sci 1997; 61: 1705-1712.

151. Luboshitzky R, Zabari Z, Shen-Orr Z, Herer P, Lavie P. Disruption of the nocturnal testosterone rhythm by sleep fragmentation in normal men. J Clin Endocrinol Metab 2001; 86: 1134-1139.

152. Singer F, Zumoff B. Subnormal serum testosterone levels in male internal medicine residents. Steroids 1992; 57: 86-89.

153. Kouchiyama S, Masuyama S, Shinozaki T, et al. Prediction of the degree of nocturnal oxygen desaturation in sleep apnea syndrome by estimating the testosterone level. Nihon Kyobu Shikkan Gakkai Zasshi 1989; 27: 941-945.

154. Kouchiyama S, Honda Y, Kuriyama T. Influence of nocturnal oxygen desaturation on circadian rhythm of testosterone secretion. Respiration 1990; 57: 359-363.

155. Aasebo U, Gyltnes A, Bremnes RM, Aakvaag A, Slordal L. Reversal of sexual impotence in male patients with chronic obstructive pulmonary disease and hypoxemia with longterm oxygen therapy. J Steroid Biochem Molec Biol 1993; 46: 799-803.

156. Semple PA, Graham A, Malcolm Y, Beastall GH, Watson WS. Hypoxia, depression of testosterone, and impotence in pickwickian syndrome reversed by weight reduction. $\mathrm{Br} \mathrm{Med}$ J Clin Res Educ 1984; 289: 801-802.

157. Davis S. Androgen replacement in women: a commentary. J Clin Endocrinol Metab 1999; 84: 1886-1891.

158. Polo O, Berthon-Jones M, Douglas NJ, Sullivan CE. Management of obstructive sleep apnoea/hypopnoea syndrome. Lancet 1994; 344: 656-660.

159. Saini J, Krieger J, Brandenberger G, Wittersheim G, Simon C, Follenius M. Continuous positive airway pressure treatment. Effects on growth hormone, insulin and glucose profiles in obstructive sleep apnea patients. Horm Metab Res 1993; 25: 375-381

160. Cooper BG, White JE, Ashworth LA, Alberti KG, Gibson GJ. Hormonal and metabolic profiles in subjects with obstructive sleep apnea syndrome and the effects of nasal continuous positive airway pressure (CPAP) treatment. Sleep 1995; 18: 172-179.

161. Follenius M, Krieger J, Krauth MO, Sforza E, Brandenberger G. Obstructive sleep apnoea treatment: peripheral and central effects on plasma renin activity and aldosterone. Sleep 1991; 14: 211-217.

162. Grunstein R, Stewart DA, Lloyd H, Akinci M, Cheng N, Sullivan CE. Acute withdrawal of nasal CPAP in obstructive sleep apnea does not cause a rise in stress hormones. Sleep 1996; 19: 774-782.
163. Saarelainen S, Hasan J, Siitonen S, Seppälä E. Effect of nasal CPAP treatment on plasma volume, aldosterone and 24-h blood pressure in obstructive sleep apnoea. J Sleep Res 1996; 5: 181-185.

164. Krieger J, Follenius M, Sforza E, Brandenberger G, Peter JD. Effects of treatment with nasal continuous positive airway pressure on atrial natriuretic peptide and arginine vasopressin release during sleep in patients with obstructive sleep apnoea. Clin Sci 1991; 80: 443-449.

165. Ichioka M, Hirata Y, Inase N, et al. Changes of circulating atrial natriuretic peptide and antidiuretic hormone in obstructive sleep apnea syndrome. Respiration 1992; 59: 164-168.

166. Spiegel K, Follenius M, Krieger J, Sforza E, Brandenberger G. Prolactin secretion during sleep in obstructive sleep apnoea patients. J Sleep Res 1995; 4: 56-62.

167. Gislason T, Hedner J, Terenius L, Bisette G, Nemeroff CB. Substance $\mathrm{P}$, thyrotropin-releasing hormone, and monoamine metabolites in cerebrospinal fluid in sleep apnea patients. Am Rev Respir Dis 1992; 146: 784-786.

168. Brooks B, Cistulli PA, Borkman M, et al. Obstructive sleep apnea in obese noninsulin-dependent diabetic patients: effect of continuous positive airway pressure treatment on insulin responsiveness. J Clin Endocrinol Metab 1994; 79: 16811685.

169. Smurra M, Philip P, Taillard J, Guilleminault C, Bioulac B, Gin H. CPAP treatment does not affect glucose-insulin metabolism in sleep apneic patients. Sleep Med 2001; 2: 207213.

170. Shimizu K, Chin K, Nakamura T, et al. Plasma leptin levels and cardiac sympathetic function in patients with obstructive sleep apnoea-hypopnoea syndrome. Thorax 2002; 57: 429434.

171. Grunstein RR. Metabolic aspects of sleep apnea. Sleep 1996; 19: S218-S220.

172. Isozaki O, Tsushima T, Miyakawa M, Demura H, Seki H. Interaction between leptin and growth hormone (GH)/IGF-I axis. Endocr J Suppl 1999; 46: S17-S24.

173. Randeva HS, Murray RD, Lewandowski KC, et al. Differential effects of GH replacement on the components of the leptin system in GH-deficient individuals. $J$ Clin Endocrinol Metab 2002; 87: 798-804.

174. Grosfeld A, Zilberfarb V, Turban S, Andre J, Guerre-Millo M, Issad T. Hypoxia increases leptin expression in human PAZ6 adipose cells. Diabetologia 2002; 45: 527-530.

175. Ambrosini G, Nath AK, Sierra-Honigmann MR, FloresRiveros J. Transcriptional activation of the human leptin gene in response to hypoxia: involvement of hypoxiainducible factor 1. J Biol Chem 2002; 277: 34601-34609.

176. Tschöp M, Strasburger CJ, Hartmann G, Biollaz J, Bärtsch P. Raised leptin concentrations at high altitude associated with loss of appetite. Lancet 1998; 352: 1119-1120.

177. Saaresranta T, Irjala K, Polo O. Effect of medroxyprogesterone acetate on arterial blood gases, serum leptin levels, and neuropeptide Y. Eur Respir J 2002; 18: 989-995.

178. Rodenstein DO, D'Odemont JP, Pieters T, Aubert-Tulkens G. Diurnal and nocturnal diuresis and natriuresis in obstructive sleep apnea. Effects of nasal continuous positive airway pressure therapy. Am Rev Respir Dis 1992; 145: 13671371.

179. Minemura H, Akashiba T, Yamamoto H, Akahoshi T, Kosaka N, Horie T. Acute effects of nasal continuous positive airway pressure on 24-hour blood pressure and catecholamines in patients with obstructive sleep apnea. Intern Med 1998; 37: 1009-1013.

180. Ip MSM, Lam B, Chan L-Y, et al. Circulating nitric oxide is suppressed in obstructive sleep apnea and is reversed by nasal continuous positive airway pressure. Am J Respir Crit Care Med 2000; 162: 2166-2171.

181. Pietrowsky R, Meyrer R, Kern W, Born J, Fehm HL. Effects of diurnal sleep on secretion of cortisol, luteinizing hormone, and growth hormone in man. J Clin Endocrinol Metab 1994; 78: $683-687$. 
182. Pincus SM, Mulligan $\mathrm{T}$, Iranamanesh $\mathrm{A}$, Gheorghiu $\mathrm{S}$, Godschalk M, Veldhuis JD. Older males secrete luteinizing hormone and testosterone more irregularly, and jointly more asynchronously, than younger males. Proc Natl Acad Sci USA 1996; 93: 14100-14105.

183. Luboshitzky R, Herer P, Levi M, Shen-Orr Z, Lavie P Relationship between rapid eye movement sleep and testosterone secretion in normal men. $J$ Androl 1999; 20: 731-737.

184. Young T, Evans L, Finn L, Palta M. Estimation of the clinically diagnosed proportion of sleep apnea syndrome in middle-aged men and women. Sleep 1997; 20: 705-706.

185. Polo O. Continuous positive airway pressure for treatment of sleep apnoea. Lancet 1999; 353: 2086-2087. 